\title{
Endüstriyel Topraklardaki PAH Kirliliğinin UVC Uygulamalarıyla Gideriminde Katkı Maddesi Kullanımının Etkileri
}

\section{The Effects of the Use of Additives in the Removal of PAH Pollution from Industrial Soils with UVC Applications}

\author{
Burcu Şengül 1 1ㅇ, Gizem Eker Şanlı $2^{*}(\mathbb{b}$ \\ 1,2 Bursa Uludağ Üniversitesi Mühendislik Fakültesi Çevre Mühendisliği Bölümü, Bursa, TÜRKiYE \\ Sorumlu Yazar / Corresponding Author *: geker@uludag.edu.tr
}

Öz

Bu çalışmada, Bursa'da bir çimento fabrikası yakınından alınan toprak örneklerindeki poliaromatik hidrokarbonların (PAH'ların), ultraviyole-C (UVC) ve ultraviyole-C/hidrojen peroksit (UVC- $\mathrm{H}_{2} \mathrm{O}_{2}$ ) uygulamaları ile giderilebilirliğinin ortaya konması amaçlanmıștır. Sırasıyla toprak kuru ağırlığının $\% 0, \% 1, \% 10$ ve $\% 20$ 'si kadar $\mathrm{H}_{2} \mathrm{O}_{2}$ örneğe ilave edilmiş ve UVC ile 24 saatlik PAH giderim uygulamaları gerçekleștirilmiștir. Giderim süreci sonunda hem toprakta kalan PAH'lar belirlenerek giderim verimleri hesaplanmış hem de topraktan buharlaşarak iç ortam havasında biriken PAH'ların poliüretan köpük (PUF) kolonundan geçirilerek örneklenmesi sağlanmıştır. Ultrasonik yöntemle ekstrakte edilen örneklerde PAH ölçümleri, Gaz Kromatografisi-Kütle Spektrometresi (GC-MS) cihazıyla yapılmıştır. $30{ }^{\circ} \mathrm{C}^{\prime} \mathrm{de}$, UVC ışığının kullanımıyla toplam $12 \mathrm{PAH}\left(\sum 12 \mathrm{PAH}\right)$ için giderim verimlerinde $\% 9^{\prime}$ luk artıs tespit edilmiștir. UVC- $\mathrm{H}_{2} \mathrm{O}_{2}$ uygulamalarında $\sum_{12} \mathrm{PAH}$ giderim verimleri $\% 0, \% 1, \% 10$ ve $\% 20 \mathrm{H}_{2} \mathrm{O}_{2}$ içeren örnekler için sırasıyla \%90, \%70, \%46 ve \%71 olarak hesaplanmış ve $\mathrm{H}_{2} \mathrm{O}_{2}$ 'nin $30{ }^{\circ} \mathrm{C}$ 'de $\mathrm{PAH}$ giderimi için etkin bir katkı maddesi olmadığı kanaatine varılmıştır. UVC- $\mathrm{H}_{2} \mathrm{O}_{2}$ uygulamaları sonrasında topraktan havaya geçen PAH'ların \%70'inin 3 halkalılardan ve \%3'ünün 4 halkalılardan oluştuğu tespit edilmiştir.

Anahtar Kelimeler: Fotoparçalanma, Halka Dağılımı, $\mathrm{H}_{2} \mathrm{O}_{2}$, PUF, Toprak

\section{Abstract}

The aim of this study is to removal of polycylic aromatic hydrocarbons (PAHs) from soil samples with ultraviolet-C (UVC) and ultraviolet-C/hydrogen peroxide (UVC- $\mathrm{H}_{2} \mathrm{O}_{2}$ ) applications. Soils were taken from an area near a cement factory in Bursa. $\mathrm{H}_{2} \mathrm{O}_{2}$ was added to the samples at the doses of $0 \%, 1 \%, 10 \%$ and $20 \%$ of dry soil weight and PAH removal applications were carried out during 24 hours. At the end of the removal process, the PAHs remaining in the soil were determined and the removal efficiencies were calculated. Besides, the PAHs accumulated in the indoor air by evaporating from the soil were sampled with polyurethane foam (PUF) column. The samples were extracted with ultrasonic method and PAHs were analyzed with the Gas Chromatography-Mass Spectrometry (GC-MS). Total $12 \mathrm{PAH}\left(\sum_{12} \mathrm{PAH}\right)$ removal efficiency was increased by $9 \%$ with the use of UVC light at $30{ }^{\circ} \mathrm{C}$. In UVC- $\mathrm{H}_{2} \mathrm{O}_{2}$ applications, $\sum 12 \mathrm{PAH}$ removal efficiencies were calculated as 
DEÜ FMD 23(68), 369-380, 2021

$90 \%, 70 \%, 46 \%$ and $71 \%$ for samples containing $0 \%, 1 \%, 10 \%$ and $20 \% \mathrm{H}_{2} \mathrm{O}_{2}$, respectively. It was concluded that $\mathrm{H}_{2} \mathrm{O}_{2}$ was not effective for $\mathrm{PAH}$ removal at $30{ }^{\circ} \mathrm{C}$. After UVC- $\mathrm{H}_{2} \mathrm{O}_{2}$ applications, it was determined that $70 \%$ of evaporated PAHs consist of 3-ring PAHs and 3\% consist of 4-ring PAH species.

Keywords: $\mathrm{H}_{2} \mathrm{O}_{2}$, Photodegradation, PUF, Ring Distribution, Soil

\section{Giriş}

Polisiklik aromatik hidrokarbonlar (PAH'lar), 2-7 halkalı hidrokarbon bileşikleri olup, her türlü yanma prosesi sonucu atmosfere verilen ve 100 den fazla farklı türü içinde barındıran kimyasal bir gruptur. Birçok PAH bileşiği besin zinciri yoluyla insan vücuduna alındığında mutajenik ve/veya kanserojenik etki potansiyeline sahiptir [1]. Bu bileșikler hava, su toprak gibi tüm çevresel ortamlarda bulunurlar. Havada olușup yağıșlarla ve toz parçalarıyla çökelerek suya ve toprağa geçerler. Topraktaki PAH'lar buharlaşma, fotoliz ve oksidasyon gibi abiyotik bozunma, biyobozunma ve bitkilerde birikme olaylarıyla uzaklaştırılırlar. Ayrıca yeraltı sularına sızarak akiferler vasıtasıyla farklı mesafelere taşınabilirler [2,3].

Toprak, PAH'lar için, karasal çevredeki en önemli rezerv alanıdır. Toprak, bu kirleticiler için doğal bir alıcı ortam gibi davranır [4] PAH'lar, hidrofobik olup, suda düşük çözünürlüğe sahip olduklarından, toprak ve sedimentte bulunan organik maddelere bağlanma eğilimi gösterirler ve partikül madde üzerine adsorbe edilerek, birikirler [5,6]. PAH'ların halka sayıları ve dolayısıyla moleküler ağırlıkları arttıkça, sudaki çözünürlükleri ve uçuculukları azalmaktadır. Bu nedenle, toprakta parçalanmaları güçleşir, oksidasyon ve indirgenmeye karşı dirençleri $\operatorname{artar}[7,8]$.

PAH'lar topraklarda dirençli bir yapı gösteren oldukça kararlı kirleticilerdir ve diğer birçok organik kirletici maddelere klyasla parçalanmaları zordur. PAH ile kirlenmiș toprakların ıslah ve iyileștirilmesinde, farklı fiziksel, kimyasal, termal ve biyolojik yöntemler kullanılmaktadır. Uygulanacak yöntemin seçimi, kirletici türü, kirlenmiş toprağın iyileştirme sonrası kullanımı, toprak türü ve özellikleri, ortamda girișim yapabilecek maddelerin varlığı ve maliyet gibi faktörlere bağlıdır [6].

Topraktaki PAH'ların gideriminde biyolojik parçalama, fitoremediasyon, fotoparçalama [9], elektroremediasyon [10] gibi yöntemlerin kullanımına yönelik çeșitli çalışmalar yer almaktadır. Güneș ıșığı varlığında gerçekleşen fotoparçalama ekolojik düzen içinde doğal yolla gerçekleşen başlıca PAH giderim yöntemlerinden biridir. Fotoparçalanma yoluyla PAH giderimi, bu bileşiklerin kararlı yapılarının bozulması esasına dayanır. Morötesi (UV) ıșınların PAH'ların gideriminde kullanılabildiği çeşitli araştırmacılar tarafından ortaya konmuștur [11-13]. Kısa dalga boylu UV ıșınları PAH'lardaki benzen halkasını parçalayabilecek kadar yüksek bir enerjiye sahiptir $[9,14]$. Fotoparçalanma çalıșmalarında çeșitli katkı maddeleri ve kimyasalların kullanımı ile yüksek oranda $\mathrm{PAH}$ giderimi sağlanabilmektedir. $\mathrm{H}_{2} \mathrm{O}_{2}$, hidroksil radikali $\left(\mathrm{OH}^{\cdot}\right)$ üreterek $\mathrm{PAH}$ giderim oranlarının artmasını sağlamaktadır $[15,16]$.

$\mathrm{H}_{2} \mathrm{O}_{2}$, bilinen en güçlü oksitleyicilerden biridir ve temel olarak, ağartma prosesleri, kimyasal sentez, su ve atıksu arıtımı, içme sularından organik madde, mangan ve demir giderimi gibi oksidasyon reaksiyonlarında kullanılmaktadır [17]. $\mathrm{H}_{2} \mathrm{O}_{2}$ 'nin oksitleyici etkisi, moleküler haldeki oksidatif özelliklerinin doğrudan sonucu olmayıp, ondan türetilen güçlü oksidan türlerin aktivitesi sonucudur. $\mathrm{H}_{2} \mathrm{O}_{2}$, singlet oksijen, süperoksit radikali, $\mathrm{OH}$. gibi güçlü oksidatif türlerin önemli bir kaynağıdır [18]. $\mathrm{H}_{2} \mathrm{O}_{2}$, için oksidasyon potansiyeli $1,78 \mathrm{~V}$ iken, oluşan OH.'ın oksidasyon potansiyeli 2,80 V'tur [19]. $\mathrm{H}_{2} \mathrm{O}_{2}$ uygulamalarının, diğer toprak iyileștirme yöntemlerine göre, bazı avantaj ve dezavantajları mevcuttur. $\mathrm{H}_{2} \mathrm{O}_{2}$ oksidasyonunun nispeten hızlı olması, kirleticilerin zararsız ve doğal ürünlere dönüşümü ve topraktaki doğal demir oksit mineralleri ile reaksiyona girebilmesi avantajları arasında sayılabilir. $\mathrm{pH}$ kontrolü gerektirmesi, özellikle alkali topraklarda karbonatın radikal sönümleme etkisi sebebi ile proses veriminin düşmesi ise dezavantajlarındandır [20].

$\mathrm{H}_{2} \mathrm{O}_{2}$, oksitleyici olarak tek başına kullanıldığında, yüksek dozlar ve yüksek temas süreleri gerekmektedir. $\mathrm{UV} / \mathrm{H}_{2} \mathrm{O}_{2}$ prosesinde ise, sinerjistik bir etki meydana gelmekte ve UV ışığl (200-280 nm), $\mathrm{H}_{2} \mathrm{O}_{2}$ tarafından absorbe edildiğinde, peroksidik bağın kırılması sonucu iki OH·oluşmaktadır [19]. 
$\mathrm{UV} / \mathrm{H}_{2} \mathrm{O}_{2}$ prosesi, son yllarda, sulardaki çeșitli kirleticilerin uzaklaştırılmasında oldukça yaygın olarak kullanılan bir prosestir. Bensalah vd. [21] $\mathrm{UV} / \mathrm{H}_{2} \mathrm{O}_{2}$ prosesi ile tannik asit giderilebilirliğini inceledikleri çalışmalarında, \%90'ın üzerinde giderim verimi elde edildiğini bildirmişlerdir. Hastane atıksularının farklı proseslerle arıtılabilirliğinin incelendiği bir çalışmada, $\mathrm{UV} / \mathrm{H}_{2} \mathrm{O}_{2}$ prosesi ile yüksek oranda antibiyotik gideriminin sağlandığı vurgulanmıştır [22]. $\mathrm{UV} / \mathrm{H}_{2} \mathrm{O}_{2}$ prosesinin, çeșitli alifatik ve aromatik bileșikler içeren suların arıtılmasında etkili olduğu kanıtlanmıştır [23]. Literatürde, $\mathrm{UV} / \mathrm{H}_{2} \mathrm{O}_{2}$ prosesinin atıksulardan ve yüzeysel sulardan $\mathrm{PAH}$ gideriminde kullanılabilirliğini ortaya koyan çalışmaların yanında [24-27], katı matrikslerden $\mathrm{UV} / \mathrm{H}_{2} \mathrm{O}_{2}$ prosesi ile $\mathrm{PAH}$ gideriminin gerçekleștirildiği çalışmalarda mevcuttur [28,29]. Bu çalıșma, önemli bir tarım ve sanayi kenti olan Bursa'da gerçekleştrilmiş olup, endüstriyel bir bölgedeki topraklardan PAH'ların UVC uygulamalarıyla giderimi araştırılmıştır. $\mathrm{Bu}$ kapsamda, giderilen PAH'ların halka dağılımları belirlenmiș, sıcaklı̆̆ın, katkl maddesi olarak $\mathrm{H}_{2} \mathrm{O}_{2}$ kullanımının PAH giderimine etkisi ortaya konmus ve arıtma çalıșmaları sırasında buharlaşarak havaya geçen PAH miktarları tespit edilmiştir.

\section{Materyal ve Metot}

\subsection{Toprak örneklerinin alınması}

Calıșma, Bursa İli'nde bir çimento fabrikası yakınından alınan toprak örneklerinde gerçekleștirilmiștir. Bursa $\left(40^{\circ} 183^{\prime} \mathrm{N}, 29^{\circ}\right.$ $131^{\prime} E$ ), 3.056.120 kișilik nüfusuyla Türkiye'nin önemli metropolleri arasında yer alan bir tarım ve sanayi șehridir. Bursa bölgesi yoğun endüstriyel faaliyetler ve nüfus yükünün getirdiği tehditlerle karşı karşıyadır. Bölgede özellikle otomotiv, tekstil ve makine sanayinin yoğun olması çevresel kirliliğin ana kaynağını olușturmaktadır.

Çimento fabrikaları, üretim sırasında, yüksek sıcaklıkta yakma faaliyetleri içerdiğinden, atmosfere önemli miktarlarda PAH salınımı yapmaları beklenmektedir. $\mathrm{Bu}$ nedenle, örnekleme noktası olarak çimento fabrikası yakını seçilmiştir.

Toprak örnekleri, yaklașık $10 \mathrm{~m}^{2}$ lik bir alan içerisinde $0-5 \quad \mathrm{~cm}$ derinlikteki yüzeysel toprakların dört farklı noktasından alınan örneklerin karıștırılması ile elde edilmiștir.
Örnekler içerisinden büyük tașlar ve bitkiler ayıklanarak alüminyum folyoya sarılmıș, hava sızdırmaz plastik poşetlere konularak laboratuvara getirilmiştir. Toprak örneklemesi esnasında toprakta sıcaklık ölçümleri TFA Dostmann ID-Nr 48.010008 sensörleriyle yapılmıștır. Örnekler 2 mm'lik elekten elendikten sonra $10 \mathrm{~g}$ tartılarak PAH ön işlemleri için amber renkli şişeye alınmıştır [30].

Toprak pH'ı $2 \mathrm{~g}$ toprağa $5 \mathrm{~mL}$ saf su ilave edilip $(1 / 2,5) 5$ dakika karıştırıldıktan sonra Mettler Toledo marka pH metre ile ölçülmüştür. Toprak örnekleri $105{ }^{\circ}{ }^{\circ}$ 'de 24 saat bekletilerek katı madde (KM) değerleri belirlenmiştir [30]. Örneklerin toplam organik karbon (TOK) ölçümleri Standart Metodlara göre (Metod 5310B) belirlenmiştir [31]. Bunun için SSM5000 Shimadzu TOC Analizörü (TOC-V CPN) cihazı kullanılmıștır. Örneklerin PAH konsantrasyonları GC-MS'te ölçülmüştür $[11,32,33]$.

Toprak örneklerine ait bazı özellıkler Tablo 1'de verilmiştir:

Tablo 1. Toprak karakterizasyonu

\begin{tabular}{ll}
\hline Parametre & Değer \\
\hline Toprak sıcaklığı ( $\left.{ }^{\circ} \mathrm{C}\right)$ & 16 \\
Katı madde (KM) (\%) & 88 \\
Toplam organik karbon (TOK) (\%) & 2.7 \\
pH & 10.1 \\
$\begin{array}{l}\sum_{12} \text { PAH konsantrasyonu (ng/g katı } \\
\text { madde)(ng/g KM) }\end{array}$ & 4382 \\
\hline
\end{tabular}

\subsection{PAH giderim uygulamaları}

İlk olarak, petri kaplarına serilen toprak örnekleri herhangi bir ıșı kaynağ kullanılmaksızın $15^{\circ} \mathrm{C}$ ve $30^{\circ} \mathrm{C}^{\prime}$ deki düzenekte 24 saat bekletilerek termal olarak giderilen PAH miktarları belirlenmiștir. Çıkan sonuçlar ışığında daha sonraki deneyler için çalışma sicaklığı $30{ }^{\circ} \mathrm{C}$ olarak seçilmiştir. İkinci deney grubunda toprak örnekleri düzeneğe yerleştirildikten sonra UVC uygulamaları 30 ${ }^{\circ} \mathrm{C}$ 'de gerçekleştirilmiştir. Bu esnada toprağa herhangi bir kimyasal ilavesi yapılmamıștır. Son deney grubunda da, kuru toprak miktarının ağırlıkça $\% 1, \% 10$ ve $\% 20$ 'si kadar $\mathrm{H}_{2} \mathrm{O}_{2}$ toprağa dozlanmıştır. 
DEÜ FMD 23(68), 369-380, 2021

Örneklerinin düzeneğe yerleștirilmesi: Cam spatula ile 5 dakika karıștırılarak homojen hale getirilen nemli topraktan $10 \mathrm{~g}$ alınarak cam bir kabın içine konulmuştur. Belirlenen dozda $\mathrm{H}_{2} \mathrm{O}_{2}$ toprağa ilave edilip 3-5 dakika boyunca karıștırılıp homojenize edildikten sonra $8 \mathrm{~cm}$ çaplı petri kabına metal kaşık yardımıyla üzerine bastırılmadan serilmiş ve ızgara şeklinde tasarlanan ve UV kaynağından $18 \mathrm{~cm}$ uzaklıkta yer alan rafa yerleştirilmiştir. Deneysel çalışmalarda toprak örneklerinin düzenek içinde yerleștirileceği konumlar Lutron UV Radiometer-254 nm cihazıyla tespit edilmiștir. Tüm çalışmalarda petri kapları bu noktalara yerleştirilmiştir. PAH giderim uygulaması sonunda toprak örnekleri düzenekten çlkarılmıs ve $\mathrm{PAH}$ ön analiz işlemlerinden geçirildikten sonra GC-MS'te PAH ölçümleri yapılmıştır.

\subsection{Topraktan buharlasan PAH'ların} örneklenmesi

Düzeneğe PAH'tan arındırılmıș hava vermek amacıyla, girișe poliüretan köpük (PUF) kolonu yerleștirilmiștir. 24 saatlik $\mathrm{PAH}$ giderim uygulamaları sırasında iç ortam havası vakumlanarak düzenek çıkışındaki PUF kolonundan geçirilmiștir. Bu işlem ile giderim çalışmaları sırasında topraktan havaya geçen PAH bileșiklerinin türleri ve miktarları ortaya konması amaçlanmıștır.

PUF kolonları düzenek giriș ve çıkıșına yerleștirilerek iç ortam havası $0,8 \mathrm{~m}^{3} / \mathrm{sa}^{\prime}$ lik debiyle vakumlanmıştır. Düzeneğe giren temizlenmiş hava içeride $\sim 6$ sn kalmıștır. Örneklemeden sonra PUF kartuşlar 1:1 (v/v) Aseton/Hegzan (ACE/HEX) karıșımıyla 24 saat Soxhlet ekstrasiyonuna tabi tutulmuștur. Ekstraksiyon sonrasında toprak örneklerine uygulanan işlemler, ekstrakte edilen PUF örneklerine de uygulanmıștır. PUF kartuşları ilk kullanımdan önce distile su, metanol $(\mathrm{MeOH})$, ACE/HEX (1:1) ve diklorometan (DCM) ile 24 saat Soxhlet ekstraksiyonuna tabi tutulmuş ve sonra $60^{\circ} \mathrm{C}^{\prime}$ de kurutulmuștur $[34,35]$.

Yirmi dört saatlik PAH giderim uygulamaları sonunda topraktan havaya geçen PAH miktarları aşağıdaki eşitlik (1) kullanılarak hesaplanmıștır:

$$
H G P A H=H P A H / V H H
$$

HGPAH: Havaya geçen PAH konsantrasyonu $\left(\mathrm{ng} / \mathrm{m}^{3}\right)$

$$
\text { HPAH: Havada ölçülen PAH (ng) }
$$

$V H H$ : Vakumlanan hava hacmi $\left(\mathrm{m}^{3}\right)$

\subsection{PAH giderim verimlerinin hesaplanması} Her bir PAH giderim uygulaması sonunda toprakta kalan PAH konsantrasyonu ve toprakta bașlangıçtaki PAH konsantrasyonu dikkate alınarak \% $\mathrm{PAH}$ giderim verimleri hesaplanmıștır. \%PAH giderim verimlerinin hesaplanmasında kullanılan eşitlik (2) aşağıdaki gibidir:

$$
\% P A H G V=\frac{G P A H-K P A H}{G P A H} \times 100
$$

\%PAH Giderim Verimi (\%PAH GV): 24 saatlik $\mathrm{PAH}$ giderim uygulaması sonundaki $\mathrm{PAH}$ giderim verimi

Giriș $\mathrm{PAH}_{\text {toprak }}$ (ng/g KM) (GPAH): PAH giderim uygulaması öncesinde topraktaki $\mathrm{PAH}$ konsantrasyonu

Kalan $\mathrm{PAH}_{\text {toprak }}$ (ng/g KM) (KPAH): PAH giderim uygulaması sonunda toprakta kalan PAH konsantrasyonu

\subsection{PAH ön analiz işlemleri ve GC-MS ölçümleri}

Topraktan $10 \mathrm{~g}$ tartılarak üzerine hacimce 1/1 oranında $30 \mathrm{~mL}$ 'lik diklorometan/petroleteri (DCM/PE)(Merck, M106054/ Merck, M101769) karıșımı ve $1 \mathrm{~mL}$ verim standardı ilave edilmiştir. Düzenekte geçekleştirilen PAH giderim uygulamaları sonunda toprak örneklerine $30 \mathrm{~mL} \mathrm{DCM} / \mathrm{PE}(1 / 1)$ ve $4 \mathrm{ng} / \mathrm{mL}$ Standard Mix A PAH verim standardından $1 \mathrm{~mL}$ ilave edilmiștir. Verim standartları içindeki farklı türler belli PAH türlerinin verimlerini belirlemek için kullanılmıștır. Fenantren- $\mathrm{d}_{10}$ (Phe, Ant, Fl, Pyr ve BaA'nın standardı), Krisen$\mathrm{d}_{12}$ (Chr, BbF, BkF ve BaP'nin standardı) ve Perilen-d 12 (InP, DahA ve BghiP'nin standardı) verim standardının içindeki türlerdir. Tüm toprak örnekleri orbital çalkalayıcı da 280 rpm'de 5 saat çalkalanmıștır. Calkalayıcıdan çıkarılan örnekler ultrasonik banyoda (Elma S $80 \mathrm{H}) 3$ kere 30 'ar dakikalık sürelerle ekstrakte edilmiștir. Ekstrakte edilen örnekler Sartorius Stedim (FT-3-1103-047) cam mikrofiber filtreden geçirilerek birleștirilmiștir. Ardından elde edilen özütlerin hacmi döner 
buharlaștırıcıda $30 \mathrm{rpm}$ hız ile 5 mL'ye düşürülmüștür. 15 mL HEX (Merck, M104371) ilavesinden sonra hacim tekrar 5 mL'ye düşürülerek solvent değișimi sağlanmıștır. Hafif azot gazı yardımıyla hacim 5 mL'den 2 mL'ye indirilmiștir. Bundan sonra örnekler fraksiyonlarına ayırma işlemine tabi tutulmuştur. Fraksiyonlarına ayırma kolonu aşağıdan yukarıya doğru sırasıyla cam yünü, $3 \mathrm{~g}$ deaktive edilmiş silisik asit, 2 g deaktive edilmiş alümina ve $1 \mathrm{~cm}$ yüksekliğinde aktive edilmiș sodyum sülfat $\left(\mathrm{Na}_{2} \mathrm{SO}_{4}\right)$ içermektedir Kolon, sırasıyla $20 \mathrm{~mL}$ DCM ile $20 \mathrm{~mL}$ PE geçirilerek temizlenmiștir. 2 mL'lik örnek kolondan tamamen geçtikten sonra $25 \mathrm{~mL}$ daha PE kolona ilave edilerek poliklorlu bifenil (PCB) fraksiyonu toplanmıștır. Daha sonra kolona 20 mL DCM eklenerek PAH fraksiyonu ayrılmıștır [30,36-38].
PAH ön analizi için deneysel süreçle ilgili akım şeması Şekil 1'de verilmiştir. PAH analizinden önce, GC-MS cihazının verdiği sonuçların lineerliğini tanımlayabilmek için yedi konsantrasyon değerine göre $(0,01,0,1,0,5$, $1,25,2,5, \quad 5$, and $10 \mu \mathrm{g} / \mathrm{mL}$ ) kalibrasyon yapılmıștır. Kalibrasyon eğrisinin $r^{2}$ değeri $>0,99$ mertebesindedir. Cihazın performansı 24 saatte bir orta noktası kalibrasyon standardının analizlenmesiyle kontrol edilmiştir. PAH sonuçları toprak örneklerinin katı maddesine göre düzeltilerek konsantrasyon değerleri ng/g KM biriminde verilmiștir [39]. GC-MS'teki PAH konsantrasyonlarının ölçümüne yönelik detaylı bilgiler literatürde yer almaktadır [40].

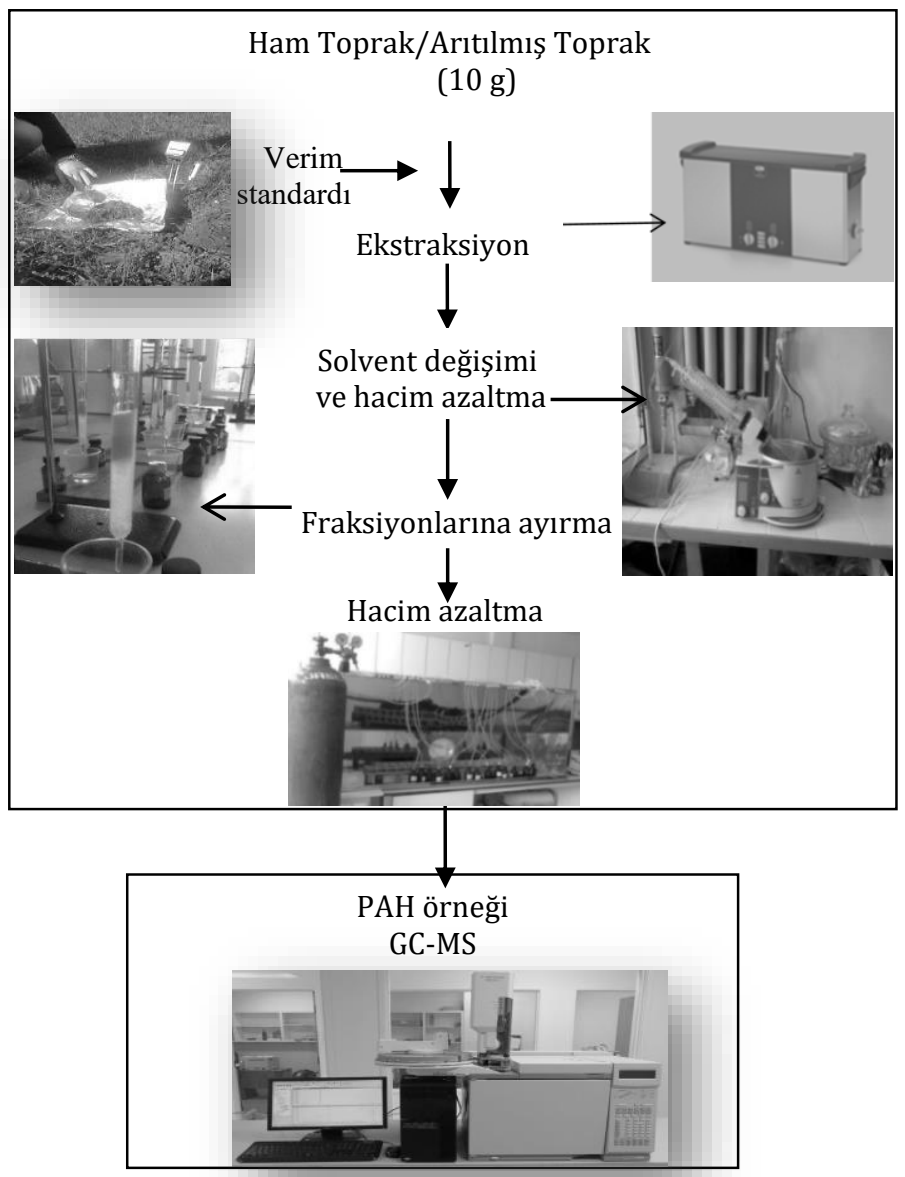

Şekil 1. PAH ön analizi akım şeması 


\subsection{Kalite güvenilirliği / Kalite kontrol}

$\mathrm{Bu}$ çalışmada, United States Environmental Protection Agency (USEPA) tarafindan belirlenen öncelikli kirleticiler listesinde yer alan 16 PAH bileşiğinin toprak örneklerindeki konsantrasyonlarının (giderim çalışmaları öncesinde ve sonrasinda) ve topraktan hava ortamına geçen miktarlarının belirlenmesi hedeflenmiștir. Ancak bu 16 bileșikten 12 tanesi rapor edilmiștir. Diğer 4 türe ait konsantrasyon değerleri verim değerlerinin düşük çıkması sebebiyle rapor edilmemiştir. $12 \mathrm{PAH}$ türü sirasılyla fenantren (Phe), antrasen (Ant), florenten $(\mathrm{Fl})$, piren (Pyr), benzo[a]antrasen $(\mathrm{BaA})$, krisen (Chr), benzo[b]florenten $(\mathrm{BbF})$, benzo[k]florenten $(\mathrm{BkF})$, benzo[a]piren $(\mathrm{BaP})$, indeno[1,2,3-c,d]piren (InP), dibenzo(a,h) antrasen (DahA), benzo(g,h,i)perilen (BghiP) olarak sıralanabilir. Toprak örnek sayısının \%10'u kadar şahit örneği hazırlanarak ișlemler sırasında herhangi bir kirlenmenin olup olmadığ örneklerinin alınması sırasında $5 \mathrm{~g}$ aktive edilmiş $\mathrm{Na}_{2} \mathrm{SO}_{4}$ içeren amber renkli șișenin ağzı açık tutularak arazi şahitleri hazırlanmıștır $[41,43]$. Toprak örneklerine uygulanan işlemler PUF ve şahit örneklerine de uygulanmıştır. Her bir örneğe (toprak, PUF ve şahit örnekleri) Standard Mix A PAH verim standardı ilave edilmiștir. PAH konsantrasyonları Agilent 7890 Model Gaz Kromotografisi (GC)'nin Agilent 5975C kütle seçicili üçlü eksenli detektörü (MSD) ile ölçülmüştür. Bu çalışmada kullanılan kimyasallar GC-Grade özelliğe sahiptir. Her bir PAH türü için belirlenme sinırları (LOD) hesaplanmıştır (LOD $=$ Şahit ort. +3 standart sapma) $[44,45]$. Tüm örneklerde PAH türlerine ait miktarlar belirlenmiș ve bu değerler LOD değeri ile kıyaslanmıştır. LOD'den küçük çıkan PAH değerleri hesaplamalara katılmamıștır.

\section{Bulgular ve Tartışma}

\subsection{Sıcaklığın ve UVC uygulamalarının toplam PAH giderimine etkisi}

UVC ışığı kullanılmadan ve kullanılarak 15 ve 30 o C'de PAH giderim uygulamaları gerçekleştirilmiş ve giderim verimleri Şekil 2'de verilmiştir. $15{ }^{\circ} C^{\prime}$ de, UVC ışığı kullanılmadan ve UVC ışığı ile gerçekleştirilen uygulamalarda, sırasıyla, \%66 ve \%82 olarak elde edilen toplam $\mathrm{PAH}$ giderim verimleri, sicaklığın 30 o C'ye çıkarılmasıyla, $\% 78$ ve $\% 86$ değerlerine ulaşmıştır. 30 oC'de daha yüksek giderim verimleri elde edildiği için, çalışmanın diğer așamalarında bu sıcaklık değeri ile çalıșmalar yürütülmüştür. UVC ıșığı kullanımı, toplam PAH gideriminde, $15{ }^{\circ} \mathrm{C}$ için $\% 16,30{ }^{\circ} \mathrm{C}$ için $\% 9$ artış sağlamıștır. UV ışınları PAH'ların fotoparçalanması için gerekli olan enerjiye sahiptir. Ișık varlığında PAH bileșiklerinin yapısındaki benzen halkası kırılabilmektedir $[9,14]$. Karaca ve Tasdemir [40] gida çamurlarında UV uygulamasının PAH'ların fotoparçalanmayla giderimini \%26 oranında daha arttırdığını tespit etmiştir. Çeşitli araștırmacılar UV ıșınlarının katı matrikslerdeki PAH'ların giderimini arttırdığını bulgulamış olup sunulan çalışmada elde edilen veriler literatürle uyumludur $[9,43,46]$.

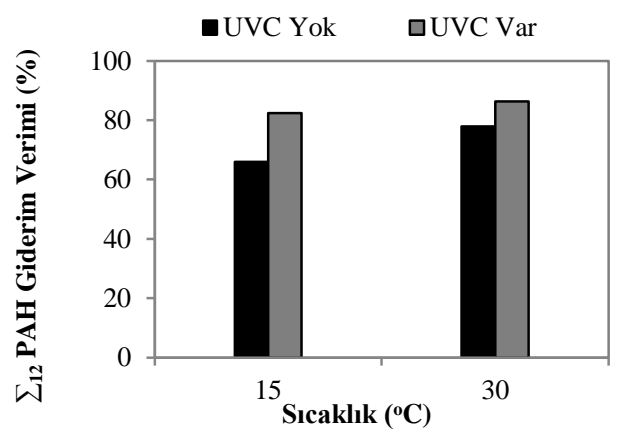

Şekil 2. Sıcaklığın $\sum \mathbf{1 2}$ PAH giderim verimine etkisi

\section{2. $\mathrm{H}_{2} \mathrm{O}_{2}$ kullanımının PAH giderimine etkisi}

UVC uygulamalarında, toprağa, kuru ağırlığın $\% 0, \% 1, \% 10$ ve $\% 20$ 'si oraninda $\mathrm{H}_{2} \mathrm{O}_{2}$ eklenerek düzenekte $30 \quad{ }^{\circ} C^{\prime}$ de yapılan çalıșmalar sonunda 12 PAH türü için elde edilen giderim verimleri Şekil 3'deki gibidir. $\mathrm{H}_{2} \mathrm{O}_{2}$ içermeyen örnekler düzenekte bekletildiğinde Chr türü hariç 3 halkalı (Phe, Ant) ve 4 halkalı (Fl, Pyr, BaA, Chr) PAH bileșiklerinin \%80'nin üzerinde bir verimle giderildiği görülmüștür. $\mathrm{H}_{2} \mathrm{O}_{2}$ içermeyen örneklerde 5-6 halkalı (BbF, $\mathrm{BkF}, \mathrm{BaP}, \mathrm{InP}, \mathrm{DahA}, \mathrm{BghiP})$ ağır $\mathrm{PAH}$ türlerinden sadece $\mathrm{BbF}$ ve $\mathrm{BkF}$ belirli oranlarda giderilmiştir. Şekil 3'de görüldüğü gibi ortama $\mathrm{H}_{2} \mathrm{O}_{2}$ eklenmesi ile farklı $\mathrm{PAH}$ türlerinin giderimine katkı konmuştur. $\% 1 \mathrm{H}_{2} \mathrm{O}_{2}$ dozunun ağır PAH türlerinden 3 tanesinin $(\mathrm{BbF}, \mathrm{BkF}$ ve $\mathrm{BaP})$ giderimine katkı koyduğu görülmüștür. $\mathrm{H}_{2} \mathrm{O}_{2}$ içermeyen örneklerde, $\mathrm{BbF}$ ve $\mathrm{BkF}$ için elde edilen giderim verimleri, sırasıyla, $\% 5$ ve 
$\% 61$ iken, ortama $\% 1 \quad \mathrm{H}_{2} \mathrm{O}_{2}$ eklenmesiyle giderim verimleri $\mathrm{BbF}, \mathrm{BkF}, \mathrm{BaP}$ için \%9, \%84 ve $\% 2$ 'ye ulaşmıștır. $\% 10$ ve $\% 20 \mathrm{H}_{2} \mathrm{O}_{2}$ ilavesi ile, ağır $\mathrm{PAH}$ türlerinin giderimi sağlanamamıştır. Düzenekteki UVC deneyleri sonunda gerek ışık kaynağının gerekse $\mathrm{H}_{2} \mathrm{O}_{2}$ 'nin varlığında olușan radikallerle yüksek moleküler ağırlıklı PAH'ların birçoğunun topraktan giderilemediği sonucuna varılmıștır.

UVC uygulamalarında termostat açıken sıcaklık $30{ }^{\circ} \mathrm{C}$ 'ye yükselmiş ve 24 saat sonunda topraktaki $\sum_{12} \mathrm{PAH}$ giderim verimleri $\% 0, \% 1$, $\% 10$ ve $\% 20 \mathrm{H}_{2} \mathrm{O}_{2}$ içeren örnekler için \%90, $\% 70, \% 46$ ve $\% 71$ olarak hesaplanmıștır (Sekil 4). $\mathrm{Bu}$ sicaklıkta, $\mathrm{H}_{2} \mathrm{O}_{2}$ kullanımının topraktaki PAH'ların giderim sürecini olumsuz yönde etkilediği görülmüştür. Yüksek enerjili UVC ışınlarının $\mathrm{H}_{2} \mathrm{O}_{2}$ varlığında radikalik oluşumlarla beraber topraktaki organik bileşikleri parçalayarak incelenen PAH bileşiklerine dönüștürmesi veya bu çalıșmada incelenmeyen diğer PAH türlerinin fotoparçalanma sonucu incelenen $\mathrm{PAH}$ türlerine dönüşmesi mümkündür. $\mathrm{Bu}$ durum, $\mathrm{PAH}$ giderim verimlerinin düşük çımmasına sebep olmuş olabilir. Nitekim, Salihoğlu vd. [39] tarafından kentsel arıtma çamurlarında UVC varlığında yapılan PAH giderim çalışmasında bazı PAH türlerinin konsantrasyonlarında artışlar gözlenmiş ve bunun olası dönüşümlerden kaynaklanmış olabileceği vurgulanmıştır.

Karaca ve Taşdemir [28], Fenton benzeri ve Fenton prosesleri ile arıtma çamurlarından PAH giderimini inceledikleri çalışmalarında, sıcaklık artışının her iki prosesi de olumsuz etkilediğini ve ortam sıcaklığ 140 ㅇ'ye ulaștığında, $\mathrm{H}_{2} \mathrm{O}_{2}$ 'nin parçalanması sebebiyle giderim verimlerinin azaldığını bildirmişlerdir. Rivas vd. [47], $30{ }^{\circ}$ C'nin üzerindeki sıcaklıklarda, verimsiz ayrışan $\mathrm{H}_{2} \mathrm{O}_{2} \quad$ yüzdesinin arttığını vurgulamıșlardır. Bu çalıșmada, ara saatlerde sıcaklık 40 o C'ye ulaştığında ortamdaki $\mathrm{H}_{2} \mathrm{O}_{2}$ 'nin parçalanmaya başlamasıyla giderim verimlerinin azaldığı düşünülmektedir. Ayrıca, bu süre sonunda reaksiyona giren $\mathrm{H}_{2} \mathrm{O}_{2}$ 'nin tükenmesi nedeniyle giderim veriminde bir düşme olabileceği de dikkate alınmalıdır.

$\mathrm{UV} / \mathrm{H}_{2} \mathrm{O}_{2}$ prosesinde, optimum doza ulaşana kadar, $\mathrm{H}_{2} \mathrm{O}_{2}$ miktarını arttırmak, giderim verimini arttırmaktadır. Ancak, $\mathrm{H}_{2} \mathrm{O}_{2}$, optimum dozdan daha yüksek miktarlarda uygulandığında, ortamdaki fazla $\mathrm{H}_{2} \mathrm{O}_{2}$, olușan $\mathrm{OH}$.'ları tüketmekte ve bu nedenle, giderim verimi düşmektedir. Ortamdaki organik bileşiklerin miktarı da, optimum $\mathrm{H}_{2} \mathrm{O}_{2}$ dozunu doğrudan etkilemektedir. Karbonat, bikarbonat gibi iyonlarında, OH.'ları tüketerek, proses verimini düşürdükleri rapor edilmiștir [48,49].

Toprak, çeşitli organik maddeleri, karbonat, bikarbonat, kalsiyum, magnezyum, demir, sodyum, potasyum gibi çeşitli iyonları bünyesinde bulunduran kompleks bir yapıdır. $\mathrm{Bu}$ kompleks yapıya, $\mathrm{H}_{2} \mathrm{O}_{2}$ uygulandığında, ortamdaki diğer organikler ve PAH'lar arasında $\mathrm{OH}$. için rekabet gerçekleşebilir. Fazla $\mathrm{H}_{2} \mathrm{O}_{2}$ veya çeşitli iyonlar sönümleme etkisi gösterebilir. Toprakta doğal olarak bulunan mineral demir ile $\mathrm{H}_{2} \mathrm{O}_{2}$ arasinda, fenton benzeri reaksiyonlar ortaya çlkabileceğinden, ortamdaki $\mathrm{H}_{2} \mathrm{O}_{2}$ azalabilir veya tükenebilir. $\mathrm{Bu}$ etkileșimler sonucunda, toplam PAH giderim veriminin azalmış olabileceği düşünülmektedir. Ferrarese vd. [50], sedimentte kimyasal oksidasyon ile PAH parçalanabilirliğini inceledikleri çalışmalarında, 50, 100, $200 \mathrm{mmol} \mathrm{H}_{2} \mathrm{O}_{2}$ ile, sirasiyla, \%52, \%96 ve \%91 toplam PAH giderimi elde etmişler ve verimin azalmasının, yüksek oksidan konsantrasyonlarının, oksidanı tüketmesinden ve sönümleme reaksiyonlarına sebep olmasından kaynaklandığını vurgulamışlardır. Kanel vd. [51], topraklarda bikarbonat/karbonat iyonu konsantrasyonu arttıkça PAH gideriminin azaldığını ve bu durumun, bikarbonat/karbonat iyonlarının $\mathrm{OH}$. sönümleme etkisinden kaynaklandığını vurgulamışlardır. Petigara vd. [52], dört farklı toprakta gerçekleştirdikleri çalışmaya göre, düşük organik madde ve mangan içeriğine sahip topraklarda, $\mathrm{H}_{2} \mathrm{O}_{2}$ dekompozisyonu yavaş, ancak $\mathrm{OH}$ oluşumu fazladır. Yüksek organik madde ve mangan içeriğine sahip topraklarda ise, $\mathrm{H}_{2} \mathrm{O}_{2}$ hızlı bir şekilde dekompoze olurken, $\mathrm{OH}$ oluşumu çok azdır. Flotron vd. [53], katı matrikste bulunan demir oksitlerin $\mathrm{H}_{2} \mathrm{O}_{2}{ }^{\prime} \mathrm{i}$ ayrıştırabildiğini, böylece Fenton benzeri proseslerin gerçekleștiğini göstermişlerdir. UVC- $\mathrm{H}_{2} \mathrm{O}_{2}$ uygulamaları sonunda hesaplanan $\sum_{12}$ PAH giderim verimleri Şekil 4'te verilmiştir. 


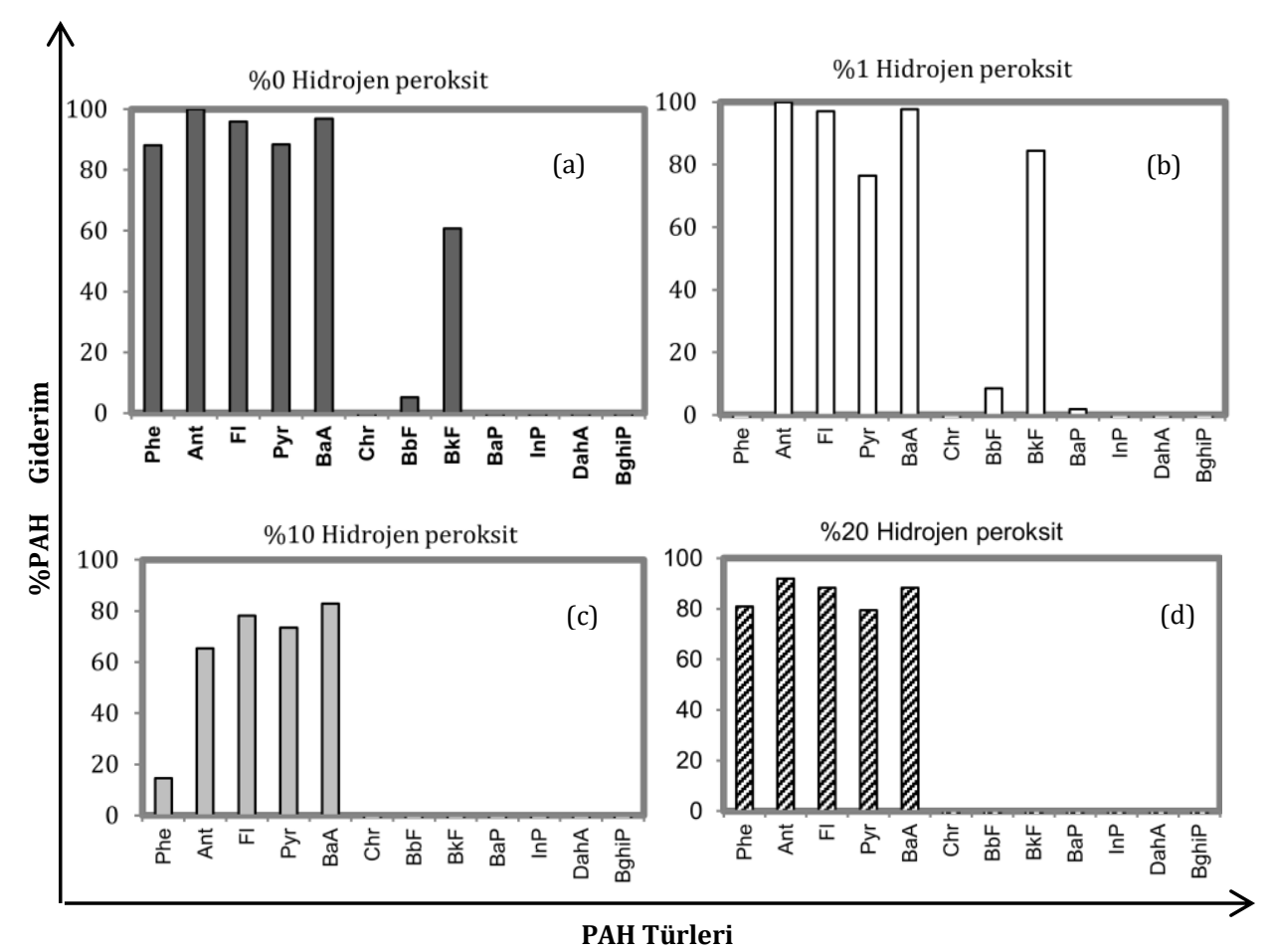

Şekil 3. UVC uygulamalarında $\mathrm{H}_{2} \mathrm{O}_{2}$ 'nin $\mathrm{PAH}$ türlerinin giderimine etkisi a) $\% 0$ Hidrojen peroksit $\quad$ b) $\% 1$ Hisrojen peroksit
c) $\% 10$ Hidrojen peroksit c) $\% 10$ Hidrojen peroksit d) $\% 20$ Hidrojen peoksit

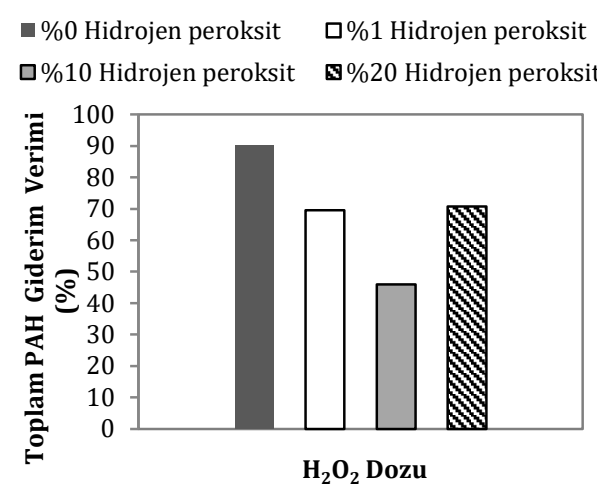

Şekil 4. UVC- $\mathrm{H}_{2} \mathrm{O}_{2}$ uygulamalarında $\mathrm{H}_{2} \mathrm{O}_{2}$ dozunun toplam $\mathrm{PAH}$ giderimine etkisi
UVC- $\mathrm{H}_{2} \mathrm{O}_{2}$ uygulamasının PAH halka gruplarının giderimi üzerindeki etkisi Şekil 5 'te verilmiştir. $\% 0 \quad \mathrm{H}_{2} \mathrm{O}_{2}$ uygulaması ile karşılaştırıldığında, genel olarak, ortama $\mathrm{H}_{2} \mathrm{O}_{2}$ ilavesinin, halka gruplarının giderimine katkı sağlamadığı, sadece $\% 1 \mathrm{H}_{2} \mathrm{O}_{2}$ uygulamasının 5-6 halkalıların giderim verimini \%5 oranında arttırdığı görülmüștür. $\mathrm{H}_{2} \mathrm{O}_{2}$ uygulamalarında en yüksek giderim $\% 1 \mathrm{H}_{2} \mathrm{O}_{2}$ ilavesi ile 4 halkalılar için elde edilmiştir.

$\% 10$ ve $\% 20 \mathrm{H}_{2} \mathrm{O}_{2}$ ilavesi ile, 3 halkalılar için $\% 13$ ve $\% 80$ ve 4 halkalılar için $\% 43$ ve $\% 63$ oranlarında giderim verimi elde edilirken, uygulanan bu $\mathrm{H}_{2} \mathrm{O}_{2}$ dozları 5-6 halkalıların giderimine katkı sağlamamıștır. 
$\square \% 0$ Hidrojen peroksit $\quad \square \% 1$ Hidrojen peroksit

口\%10 Hidrojen peroksit $\quad \square \% 20$ Hidrojen peroksit

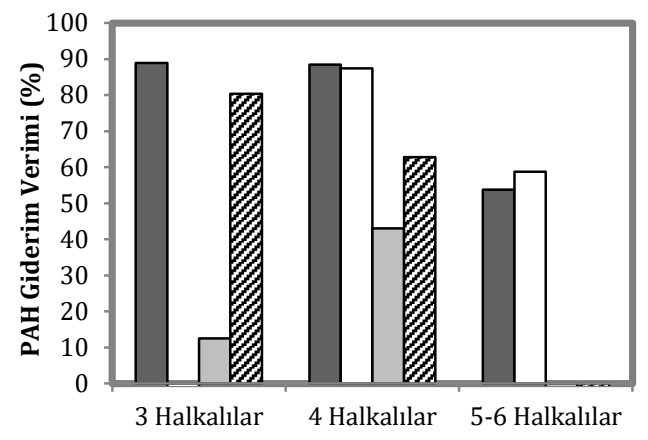

PAH Halka Grupları

Şekil 5. UVC- $\mathrm{H}_{2} \mathrm{O}_{2}$ uygulamalarında giderilen PAH'ların halka dağılımları

\subsection{PAH giderim uygulamaları sırasında} topraktaki PAH'ların havaya geçişleri

Yalnız sıcaklık uygulamaları sonrasında, havaya geçen $\mathrm{PAH}$ türlerinin konsantrasyonları Şekil 6(a)'da, UVC ve UVC- $\mathrm{H}_{2} \mathrm{O}_{2}$ uygulamaları sonrasında havaya geçen $\mathrm{PAH}$ türlerinin konsantrasyonları ise Şekil 6(b)'de verilmiştir. Şekil 6(a) incelendiğinde, $30{ }^{\circ} \mathrm{C}^{\prime}$ de havaya geçen toplam PAH konsantrasyonunun $\left(16,05 \mathrm{ng} / \mathrm{m}^{3}\right)$, $15{ }^{\circ} \mathrm{C}^{\prime}$ de havaya geçen toplam $\mathrm{PAH}$ konsantrasyonundan $\left(5,28 \mathrm{ng} / \mathrm{m}^{3}\right)$ daha fazla olduğu görülmektedir. Yüksek sıcaklıkta daha fazla PAH'ın buharlașması beklenen bir sonuçtur [37,39,43]. Benzer şekilde, Karaca [11] tarafından yapılan çalışmada birçok farklı katı matriks (arıtma çamuru, torf, bentonit) için sıcaklığın artmasıyla PAH'ların buharlaşarak havaya geçişlerinin kolaylaștığı ortaya konmuştur.

PAH'ların tür dağılımları değerlendirildiğinde, her iki sıcaklık değeri içinde, 3-4 halkalı hafif PAH türlerinin, 5-6 halkalı ağır PAH türlerine göre daha yüksek oranlarda topraktan havaya geçtikleri görülmüștür. Yüksek buhar basınçları sebebiyle buharlaşma isteği fazla olan 3 halkalı PAH'ların topraktan hava ortamına daha fazla geçmeleri beklenir. Moleküler ağırlıkları fazla olan türler katı matrikse bağlanma eğiliminde iken, düşük moleküler ağırlıklı türler buharlaşma eğilimindedir [54-56]. Bu çalıșmada, $15{ }^{\circ} \mathrm{C}$ 'de havaya geçen $\mathrm{PAH}$ oranları 3-4 halkalılar ve 5-6 halkalılar için, sırasıyla, $\% 83$ ve \%17 iken, $30{ }^{\circ} \mathrm{C}^{\prime} \mathrm{de} \% 96$ ve $\% 4$ değerlerini almıștır. UVC uygulamaları sonrasında ise, topraktan havaya geçen PAH'ların dağılımı \%92 (3 halkalılar), \%7 (4 halkalılar) ve $\% 1$ (5-6 halkalılar) olarak tespit edilmiștir. UVC- $\mathrm{H}_{2} \mathrm{O}_{2}$ uygulamaları sonrasında havadaki PAH'ların tür dağılımları incelendiğinde, \%70 (3 halkalılar), \%30 (4 halkalılar) ve \%0 (5-6 halkalılar) değerleri karşımıza çıkmaktadır. Farklı matrikslerde yapılan çalıșmalarda da, hafif PAH türlerinin buharlaşma isteklerinin ağır türlerden daha fazla olduğu ortaya konmuştur $[55,57,58]$.
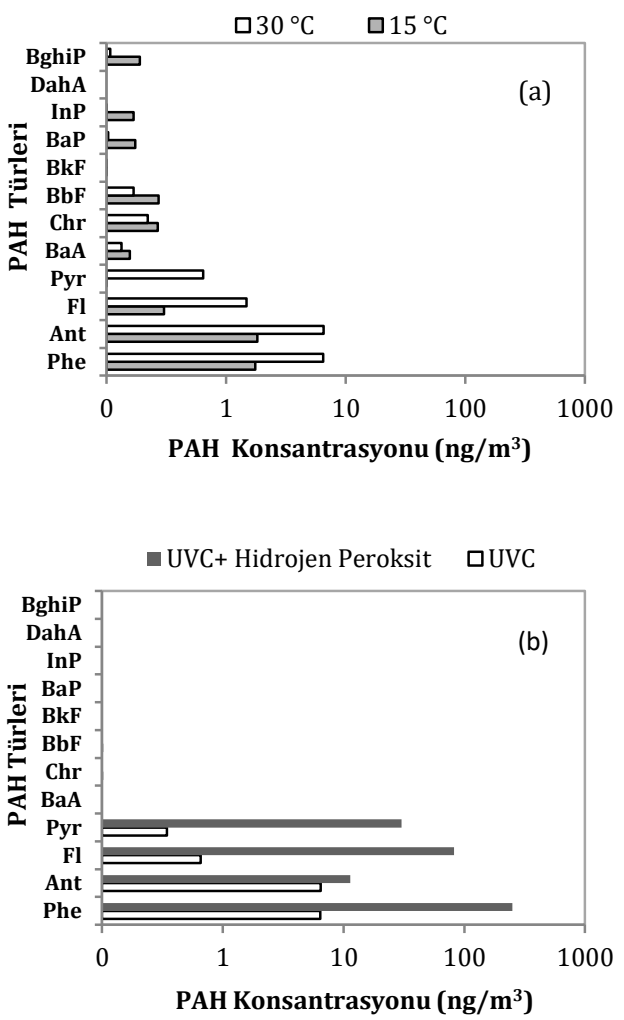

Şekil 6. PAH giderim uygulamaları sırasında topraktan havaya geçen PAH konsantrasyonları a) Sıcaklık uygulamaları (UVC yok) b) UVC ve UVC- $\mathrm{H}_{2} \mathrm{O}_{2}$ uygulamaları

\section{Sonuçlar}

PAH bileşikleri gerek lokal gerekse küresel çevre kirliğine sebep olan başlıca yarı uçucu organik bileşiklerdendir. Bu kirleticiler her ortamda bulunabilirler ve kanserojenik etkiler gösterebilirler. Su, hava, toprak gibi alıcı ortamlardaki PAH kirliliğini azaltmak/gidermek bilim camiasının üzerinde hassasiyetle durduğu çevresel konulardan biridir. Topraklardaki PAH 
kirliliğinin azaltılması için farklı yöntemlerin değerlendirilmesi mevcut soruna çözüm getirmek açısından önem taşımaktadır. Sunulan çalışmada, topraklarda PAH kaynaklı kirliliğin UV uygulamalariyla giderilebilirliği ve $\mathrm{H}_{2} \mathrm{O}_{2}$ 'in katkı maddesi olarak kullanımı araştırılmış ve giderim uygulamaları sırasında havaya geçen PAH miktarları belirlenmiştir. Çalışma neticesinde elde edilen bulgulardan öne çıkanlar aşağıda özetlenmiştir:

- UVC ıșığının uygulanması ve sıcaklığın belirli bir noktaya kadar arttırılması prosesi olumlu etkilemiş, toplam $\mathrm{PAH}$ giderimini arttırmıştır.

- $\mathrm{H}_{2} \mathrm{O}_{2}$ içermeyen örneklerde, hafif $\mathrm{PAH}$ türleri \%80'in üzerinde verimle giderilirken, ağır türlerden sadece BkF'nin giderim verimi $\% 60$ 'a ulașmıștır.

- Ortama \%1, \%10 ve \%20 dozlarında $\mathrm{H}_{2} \mathrm{O}_{2}$ eklenmesi, toplam PAH giderimine katkı sağlamamıștır. $\mathrm{Bu}$ çalıșmanın şartlarında, UVC- $\mathrm{H}_{2} \mathrm{O}_{2}$ prosesinin $\mathrm{PAH}$ gideriminde etkili olmadığı görülmüştür.

- Sicaklığın artmasiyla havaya geçen PAH konsantrasyonları da artmıștır.

- Tüm PAH giderim uygulamalarinda (sıcaklık, UVC ve UVC- $\mathrm{H}_{2} \mathrm{O}_{2}$ ) 3-4 halkalıların, 5-6 halkalılara göre daha fazla havaya geçtiği tespit edilmiștir. Yüksek buhar basınçları sebebiyle hafif PAH türlerinin hava ortamına daha fazla geçiş yaptığı sonucuna varılmıștır.

UV'ye dayalı ileri oksidasyon prosesleri topraklardan PAH gideriminde önem taşıyan proseslerdir ve bu çalışmadan elde edilen veriler, bu konunun geliștirilmesine katkı sağlayacaktır. UV'ye dayalı ileri oksidasyon proseslerinde, giderim verimi, kirletici tür ve konsantrasyonu, toprak organik maddesinin özellikleri ve içeriği, toprakta doğal olarak bulunan mineraller, oksidan konsantrasyonu, $\mathrm{pH}$, radikal sönümleyiciler gibi pekçok faktörün etkisi altındadır. İleride gerçekleștirilecek çalıșmalar, bu faktörleri gözönüne alarak, daha detaylı teknik değerlendirmeleri kapsayacak şekilde yapılmalıdır. Özellikle, ortamdaki doğal demir ile Fenton benzeri reaksiyonlar gözönüne alınmalı, prosesin daha verimli gerçekleşeceği pH ve sicaklık değerleri, $\mathrm{H}_{2} \mathrm{O}_{2}$ konsantrasyonu gibi temel proses parametreleri daha detaylı çalışılmalıdır. Farklı oksidanların ve/veya remediasyon yöntemlerinin birlikte kullanılmasına yönelik çalışmaların gerçekleştirilmesi faydalı olacaktır.

\section{Teşekkür}

Bu çalışma, Türkiye Bilimsel ve Teknolojik Araştırma Kurumu'nun (TÜBITAK) 114Y833 nolu projesi tarafından desteklenmiștir. Melis HATIPPOĞLU'na, Kübra YILMAZ'a ve Sabriye SivRI'ye örnek alımı ve laboratuvar aşamasındaki özverili çalışmaları için teşekkür ederiz.

\section{Kaynakça}

[1] Lodovici, M., Venturini, M., Marini, E., Grechi, D., Dolara, P. 2003. Polycyclic Aromatic Hydrocarbons Air Levels in Florence, Italy, and Their Correlation with Other Air Pollutants, Chemosphere, Cilt. 50, s. 377-382. DOI: 10.1016/S0045-6535(02)00404-6

[2] Agency for Toxic Substances and Disease Registry (ATSDR). 1995. Toxicological Profile for Polycyclic Aromatic Hydrocarbons (PAHs). U.S. Department of Health and Human Services, Public Health Service, Atlanta, GA, 487s.

[3] Walker, C.H. 2001. Organic Pollutants: An Ecotoxicological Perspective. 1st edition. CRC Press, New York, 304 s.

[4] Li, Y.T., Li, F.B., Chen, J.J., Yang, G.Y., Wan, H.F., Zhang, T.B., Zeng, X.D., Liu, J.M. 2008. The Concentrations, Distribution and Sources of PAHs in Agricultural Soils and Vegetables from Shunde, Guangdong, China, Environmental Monitoring and Assessment, Cilt. 139, s. 61-76. DOI: 10.1007/s10661-007-9816-x

[5] Bendouz, M., Tran, L.H., Coudert, L., Mercier, G., Blais, J.F. 2017. Degradation of Polycyclic Aromatic Hydrocarbons in Different Synthetic Solutions by Fenton's Oxidation, Environmental Technology, Cilt. $38, \quad$ s. $116-127 . \quad$ DOI: 10.1080/09593330.2016.1188161

[6] Sakshi, Singh, S.K., Haritash, A.K. 2019. Polycyclic Aromatic Hydrocarbons: Soil Pollution and Remediation, International Journal of Environmental Science and Technology, Cilt. 16, s. 6489-6512. DOI: 10.1007/s13762-019-02414-3

[7] Abdel-Shafy, H.I., Mansour, M.S.M. 2016. A Review on Polycyclic Aromatic Hydrocarbons: Source, Environmental Impact, Effect on Human Health and Remediation, Egyptian Journal of Petroleum, Cilt. 25, s. 107-123. DOI: 10.1016/j.ejpe.2015.03.011

[8] Chaber, P., Gworek, B. 2020. Surface Horizons of Forest Soils for the Diagnosis of Soil Environment Contamination and Toxicity caused by Polycyclic Aromatic Hydrocarbons (PAHs), PLoS ONE, Cilt. 15. DOI: 10.1371/journal.pone.0231359

[9] Zhang, L.H., Li, P.J., Gong, Z.Q., Li, X.M. 2008. Photocatalytic Degradation of Polycyclic Aromatic Hydrocarbons on Soil Surfaces using $\mathrm{TiO}_{2}$ under UV Light, Journal of Hazardous Materials, Cilt. 158, s. 478-484. DOI: 10.1016/j.jhazmat.2008.01.119

[10]Lima, A.T., Ottosen, L.M., Heister, K., Loch, J.P.G. 2012. Assessing PAH Removal from Clayey Soil by means of Electro-osmosis and Electrodialysis, Science of the Total Environment, Cilt. 435-436, s. 1-6. DOI: 10.1016/j.scitotenv.2012.07.010

[11]Karaca, G. 2013. Arıtma Çamurları ve Nilüfer Çayı Sedimentindeki Yarı Uçucu Organik Bileșik Seviyelerinin Belirlenmesi ve Giderimlerinin 


\section{DEÜ FMD 23(68), 369-380, 2021}

Araștırılması. Uludağ Üniversitesi, Fen Bilimleri Enstitüsü, Doktora Tezi, 214s, Bursa.

[12]Zhang, H.B., Luo, Y.M., Wong, M.H., Zhao, Q.G., Zhang, G.L. 2006. Distributions and Concentrations of PAHs in Hong Kong Soils, Environmental Pollution, Cilt 141, s. 107-114. DOI: 10.1016/j.envpol.2005.08.031

[13]Wang, Y., Liu, C.S., Li, F.B., Liu, C.P., Liang, J.B. 2009. Photodegradation of Polycyclic Aromatic Hydrocarbon Pyrene by Iron Oxide in Solid Phase, Journal of Hazardous Materials, Cilt. 162, s. 716-723. DOI: 10.1016/j.jhazmat.2008.05.086

[14] Guieysse, B., Viklund, G., Toes, A.C., Mattiasson, B. 2004. Combined UV-Biological Degradation of PAHs Chemosphere, Cilt. 55, s. 1493-1499. DOI: 10.1016/j.chemosphere.2004.01.021

[15] Kakarla, P.K.C., Watts, R.J. 1997. Depth of Fenton-like Oxidation in Remediation of Surface Soil, Journal of Environmental Engineering-ASCE, Cilt. 123, s. 11-17. DOI: 10.1061/(ASCE)0733-9372(1997)123:1(11)

[16]Kulik, N., Goi, A., Trapido, M., Tuhkanen, T. 2006 Degradation of Polycyclic Aromatic Hydrocarbons by Combined Chemical Pre-oxidation and Bioremediation in Creosote Contaminated Soil, Journal of Environmental Management, Cilt. 78, s. 382-391. DOI: 10.1016/j.jenvman.2005.05.005

[17] Oppenländer, T. 2003. Photochemical Purification of Water and Air/Advanced Oxidation Processes (AOPs): Principles, Reaction Mechanisms, Reactor Concepts. Wiley-VCH Verlag GmbH \& Co. KGaA Weinheim, $353 \mathrm{~s}$.

[18] Labas, M.D., Zalazar, C.S., Brandi, R.J., Cassano, A.E 2008. Reaction Kinetics of Bacteria Disinfection Employing Hydrogen Peroxide, Biochemical Engineering Journal, Cilt. 38, s. 78-87. DOI: 10.1016/j.bej.2007.06.008

[19] Mamane, H., Shemer, H., Linden, K.G. 2007 Inactivation of E.coli, B.subtilis spores, and MS2, T4, and $\mathrm{T} 7$ phage using $\mathrm{UV} / \mathrm{H}_{2} \mathrm{O}_{2}$ Advanced Oxidation, Journal of Hazardous Material, Cilt. 146, s. 479-486. DOI: 10.1016/j.jhazmat.2007.04.050

[20] Goi, A., Trapido, M., Kulik, N. 2009. Contaminated Soil Remediation with Hydrogen Peroxide Oxidation, World Academy of Science, Engineering and Technology International Journal of Chemical and Molecular Engineering, Cilt. 3, s. 209-213.

[21]Bensalah, N., Chair, K., Bedoui, A. 2018. Efficient Degradation of Tannic Acid in Water by $\mathrm{UV} / \mathrm{H}_{2} \mathrm{O}_{2}$ Process, Sustainable Environment Research, Cilt. 28, s. 1-11. DOI: 10.1016/j.serj.2017.04.004

[22] Perini, J.A.L., Tonettib, A.L., Vidalc, C., Montagnerc, C.C., Nogueira, R.F.B. 2018. Simultaneous Degradation of Ciprofloxacin, Amoxicillin, Sulfathiazole and Sulfamethazine, and Disinfection of Hospital Effluent after Biological Treatment via Photo-Fenton Process under Ultraviolet Germicidal Irradiation, Applied Catalysis B: Environmental, Cilt. 224, s. 761-771. DOI: 10.1016/j.apcatb.2017.11.021

[23] Wang, G.S., Hsieh, S.T., Hong, C.S. 2000. Destruction of Humic Acid in Water by UV Light-Catalyzed Oxidation with Hydrogen Peroxide, Water Research, Cilt. 34 , s. 3882-3887. DOI: 10.1016/S00431354(00)00120-2

[24]Rivas, F.J., Beltran, F.J., Acedo, B. 2000. Chemical and Photochemical Degradation of Acenaphthylene. Intermediate Identification, Journal of Hazardous
Material, Cilt. 75, s. 89-98. DOI: 10.1016/S03043894(00)00196-5

[25]Shemer, H., Linden, K.G. 2007. Aqueous Photodegradation and Toxicity of the Polycyclic Aromatic Hydrocarbons Fluorene, Dibenzofuran, and Dibenzothiophene, Water Research, Cilt. 41, s. 853861. DOI: 10.1016/j.watres.2006.11.022

[26]An, Y.J., Carraway, E.R. 2002. PAH Degradation by $\mathrm{UV} / \mathrm{H}_{2} \mathrm{O}_{2}$ in Perfluorinated Surfactant Solutions, Water Research, Cilt. 36, s. 309-314. DOI: 10.1016/s0043-1354(01)00206-8

[27]Rubio-Clemente, A., Chica, E., Peñuela, G. 2019. Evaluation of the $\mathrm{UV} / \mathrm{H}_{2} \mathrm{O}_{2}$ System for Treating Natural Water with a Mixture of Anthracene and Benzo[a]pyrene at Ultra-Trace Levels, Environmental Science and Pollution Research, Cilt. 26, s. 43814392. DOI:10.1007/s11356-018-2411-6

[28]Karaca, G., Tasdemir, Y. 2015. Application of Advanced Oxidation Processes for Polycyclic Aromatic Hydrocarbons Removal from Municipal Treatment Sludge, Clean - Soil, Air, Water, Cilt. 43, s. 191-196. DOI: 10.1002/clen.201300395

[29]Eker Şanlı, G., Şengül, B. Removal of Polycyclic Aromatic Hydrocarbons (PAHs) from Industrial Soil with Solar and UV Light, Polycyclic Aromatic Compounds, Basimda. DOI: 10.1080/10406638.2018.1539018

[30]Karaca, G. 2016. Spatial Distribution of Polycyclic Aromatic Hydrocarbon (PAH) Concentrations in Soils from Bursa, Turkey, Archives of Environmental Contamination and Toxicology, Cilt. 70, s. 406-417. DOI: $10.1007 / \mathrm{s} 00244-015-0248-2$

[31]Clescerl, L.S., Greenberg, A.E., Eaton, A.D. 1998. Standard Methods for the Examination of Water and Wastewater. 20th edition. American Public Health Association/American Water Works Association/Water Environment Federation (APHA, AWWA \& WEF), Washington, U.S.A., 1325s.

[32]Sari, M.F., Esen F., Tasdemir, Y. 2020. Biomonitoring and Source Identification of Polycyclic Aromatic Hydrocarbons (PAHs) Using Pine Tree Components from Three Different Sites in Bursa, Turkey, Archives of Environmental Contamination and Toxicology, Cilt. 78, s. 646-657. DOI: 10.1007/s00244-020-00722-1

[33]Ayyıldız, E.G., Esen, F. 2020. Atmospheric Polycyclic Aromatic Hydrocarbons (PAHs) at Two Sites, in Bursa, Turkey: Determination of Concentrations, Gas-Particle Partitioning, Sources, and Health Risk, Archives of Environmental Contamination and Toxicology, Cilt. 78, s. 350-366. DOI: 10.1007/s00244-019-00698-7

[34]Esen, F., Cindoruk, S.S., Tasdemir, Y. 2006. Ambient Concentrations and Gas/Particle Partitioning of Polycyclic Aromatic Hydrocarbons in an Urban Site in Turkey, Environmental Forensics, Cilt. 7, s. 303-312. DOI: $10.1080 / 15275920600996099$

[35]Cindoruk, S.S., Tasdemir, Y. 2007. Deposition of Atmospheric Particulate PCBs in Suburban Site of Turkey, Atmospheric Research, Cilt. 85, s. 300-309. DOI: 10.1016/j.atmosres.2007.02.002

[36]Eker, G. 2017. Bursa'da Poliaromatik Hidrokarbonlardan (PAH) Kaynaklanan Toprak Kirliliği Seviyesinin Belirlenmesi ve Giderim Olanaklarının Araștırılması. Bursa Uludağ 


\section{DEÜ FMD 23(68), 369-380, 2021}

Üniversitesi, TÜBİTAK 3001 Projesi, No: 114Y833, Bursa.

[37] Eker, G., Hatipoglu, M. 2018. Effect of UV Wavelength, Temperature and Photocatalyst on the Removal of PAHs from Industrial Soil with Photodegradation Applications, Environmental Technology, Cilt. 40, s. 3793-3803. DOI: 10.1080/09593330.2018.1491635

[38]Taşdemir, Y. 2012. Bursa Topraklarındaki PCB Dağlımları ve Hava/Toprak Arakesitindeki Değişim Miktarlarının Bölgesel ve Mevsimsel Olarak Belirlenmesi. Bursa Uludağ Üniversitesi, TÜBİTAK Projesi, No: 108Y084, Bursa.

[39] Salihoglu, N.K., Karaca, G., Salihoglu G., Tasdemir Y. 2012. Removal of Polycyclic Aromatic Hydrocarbons from Municipal Sludge using UV Light, Desalination and Water Treatment, Cilt. 44, s. 324-333. DOI: $10.1080 / 19443994.2012 .691689$

[40] Karaca, G., Tasdemir, Y. 2014a. Migration of PAHs in Food Industry Sludge to the Air during Removal by UV and $\mathrm{TiO}_{2}$, Science of the Total Environment, Cilt. $488-489$, s. $356-361 . \quad$ DOI: 10.1016/j.scitotenv.2014.03.082

[41] Karaca, G., Tasdemir, Y. 2013. Removal of Polycyclic Aromatic Hydrocarbons (PAHs) from Industrial Sludges in the Ambient Air Conditions: Automotive Industry, Journal of Environmental Science and Health Part A-Toxic/Hazardous Substances \& Environmental Engineering, Cilt. 48, s. 855-861. DOI: $10.1080 / 10934529.2013 .761481$

[42]Wang, Y.W., Zhang, Q.H., Lv, J.X., Li, A., Liu, H.X., Li, G.G., Jiang, G.B. 2007. Polybrominated Diphenyl Ethers and Organochlorine Pesticides in Sewage Sludge of Wastewater Treatment Plants in China Chemosphere, Cilt. 68, s. 1683-1691. DOI: $10.1016 /$ j.chemosphere.2007.03.060

[43] Karaca, G., Taşdemir, Y. 2011. Effect of Diethylamine on PAH Removal from Municipal Sludge under UV Light, Fresenius Environmental Bulletin, Cilt. 20, s. 1777-1784.

[44]Stevens, J.L., Northcott, G.L., Stern, G.A., Tomy, G.T. Jones, K.C. 2003. PAHs, PCBs, PCNs, Organochlorine Pesticides, Synthetic Musks, and Polychlorinated nAlkanes in U.K. Sewage Sludge: Survey Results and Implications, Environmental Science and Technology, Cilt. 37, s. 462-467. DOI: 10.1021/es020161y

[45] Tasdemir, Y., Odabasi, M., Vardar, N., Sofuoglu, A Murphy, T.J., Holsen, T.M. 2004. Dry Deposition Fluxes and Velocities of Polychlorinated Biphenyls (PCBs) associated with Particles, Atmospheric Environment, Cilt. 38, s. 2447-2456. DOI: 10.1016/j.atmosenv.2004.02.006

[46]Jonsson, S., Persson, Y., Frankki, S., van Bavel, B. Lundstedt, S., Haglund, P., Tysklind, M. 2007. Degradation of Polycyclic Aromatic Hydrocarbons (PAHs) in Contaminated Soils by Fenton's Reagent: A Multivariate Evaluation of the Importance of Soil Characteristics and PAH Properties, Journal of Hazardous Materials, Cilt. 149, s. 86-96. DOI: 10.1016/j.jhazmat.2007.03.057

[47] Rivas, F.J., Beltran, F., Gimeno, O., Carvalho. F. 2003. Fenton-like Oxidation of Landfill Leachate, Journal of Environmental Science and Health, Part AToxic/Hazardous Substances \& Environmental Engineering, Cilt. 38, s. 371-379. DOI: 10.1081/ESE120016901
[48]Sapach, R., Viraraghavan, T. 1997. An Introduction to the Use of Hydrogen Peroxide and Ultraviolet Radiation: An Advanced Oxidation Process, Journal of Environmental Science and Health, Part AToxic/Hazardous Substances \& Environmental Engineering, Cilt. 32, s. 2355-2366. DOI: $10.1080 / 10934529709376686$

[49]Bekbölet, M. 2010. Fundamentals of Advanced Oxidation Processes. ss 13-21. Belgiorno, V., Naddeo, V., Rizzo, L., ed. 2010. Water, Wastewater and Soil Treatment by Advanced Oxidation Processes(AOPs), SEED, Fisciano, Italy, 272s.

[50]Ferrarese, E., Andreottola, G., Oprea, I.A. 2008. Remediation of PAH-Contaminated Sediments by Chemical Oxidation, Journal of Hazardous Materials, Cilt. 152, s. 128-139. DOI: 10.1016/j.jhazmat.2007.06.080

[51]Kanel, S.R., Neppolian, B., Jung, H., Choi, H. 2004. Comparative Removal of Polycyclic Aromatic Hydrocarbons Using Iron Oxide and Hydrogen Peroxide in Soil Slurries, Environmental Engineering Science, Cilt. 21, s. 641-751. DOI: 10.1089/ees.2004.21.741

[52]Petigara, B.R., Blough, N.V., Mignerey, A.C. 2002. Mechanisms of Hydrogen Peroxide Decomposition in Soils, Environmental Science\&Technology, Cilt. 36, s. 639-645. DOI: 10.1021/es001726y

[53]Flotron, V., Delteil, C., Padellec, Y., Camel, V. 2005. Removal of Sorbed Polycyclic Aromatic Hydrocarbons from Soil, Sludge and Sediment Samples Using the Fenton's Reagent Process, Chemosphere, Cilt. 59, s. 1427-1437. DOI: 10.1016/j.chemosphere.2004.12.065

[54] Karaca, G., Tasdemir, Y. 2014b. Application of Various Methods for Removal of Polycyclic Aromatic Hydrocarbons from Synthetic Solid Matrices, Environmental Technology, Cilt. 35, s. 1840-1850. DOI: $10.1080 / 09593330.2014 .884634$

[55]Huang, X.Y., Chen, J.W., Gao, L.N., Ding, G.H., Zhao, Y.Z., Schramm, K-W. 2004. Data Evaluations and Quantitative Predictive Models for Vapor Pressures of Polycyclic Aromatic Hydrocarbons at Different Temperatures, SAR and QSAR in Environmental Research, Cilt. 15, s. 115-125. DOI: 10.1080/10629360410001665857

[56]Shi, Z., Tao, S., Pan, B., Fan, W., He, X.C., Zuo, Q., Wu, S.P., Li, B.G., Cao, J., Liu, W.X., Xu, F.L., Wang, X.J., Shen, W.R., Wong, P.K. 2005. Contamination of Rivers in Tianjin, China by Polycyclic Aromatic Hydrocarbons, Environmental Pollution, Cilt. 134, s. 97-111. DOI: 10.1016/j.envpol.2004.07.014

[57]Wang, D., Chen, J., Xu, Z., Qiao, X., Huang, L. 2005. Disappearance of Polycyclic Aromatic Hydrocarbons Sorbed on Surfaces of Pine [Pinua thunbergii] Needles under Irradiation of Sunlight: Volatilization and Photolysis, Atmospheric Environment, Cilt. 39, s.4583-4591.DOI: 10.1016/j.atmosenv.2005.04.008

[58] Hawthorne, S.B., Grabanski, C.B. 2000. Vaporization of PAHs from Sediments at Ambient Conditions, Environmental Science and Technology, Cilt. 34, s. 4348-4353. DOI: 10.1021/es001199i 